regeln, actually lived on the plains under the Harz, Dr. Nehring has proved satisfactorily by his own researches. It follows that this country must have formed a steppe during a certain portion of the Diluvial period.

If the above conclusions are right it follows that in a former epoch those parts of Central Europe which were formerly covered by the sea generally became steppes before coming into their present condition. Perhaps the Magdeburg-Halberstadt steppe extended southwards over Aschersleben and Halle into the valley of the White Elster, for Prof. Liebe has found, near Gera, fossil remains of several specimens of the large Jerboa, as also of the Souslik and other animals which have been obtained at Westeregeln. Besides, remains of the same animals, as well as those of the Saiga antelope and wild ass, have been found at several other points to the west. It follows, therefore, that the steppe must have extended considerably in that direction.

The result of these investigations is the more important as manifest traces seem to show that at the Steppe period man had already occupied the plains of middle Europe, and occasionally took up his abode even on the ancient steppe of Westeregeln.

The cause of the disappearance of the ancient steppes of Certral Europe Dr. Nehring supposes to have been the gradual increase of the forests which advanced along with the change of climate. In the Steppe period England and Scandinavia were still joined to the continent of Europe, the North Sea and the East Sea did not exist in their present extent, the Gulf Stream had a more northern direction, and the climate was drier and more severe than it now is. As the climate softened and the forests advanced from the wooded hills, the steppe animals gradually withdrew themselves towards the east, and disappeared, leaving only fossil remains to attest their former abundance.

\section{THE COLORADO BEETLE}

$\bar{W} \mathrm{E}$ have already several times referred to this destructive insect, and now that it has reached Europe we give an illustration of the creature in its various conditions, along with some notes which have been forwarded to us by Mr. Andrew Murray. The Board of Trade have reissued the circular, with a coloured illustration, referred to in our article on Our Insect Foes, vol, xv., p. 85 .

The Colorado beetle belongs to that subdivision of vegetable-feeding species known as Phytophaga. It may help the general reader to an appreciation of their place and character if we mention the Turnip flea as a British species of this section, and still nearer to it those brilliant green little gems that are to be seen in quantity on the leaves of the white nettle (Lamium album) in summer, and which in Scotland bear the colloquial name of Virgin Maries, an appellation, however, which is also there sometimes indifferently given to the ladybird. The genus in this great section to which these little insects equally with the Colorado beetle belong is named Chrysomela. It is true that its first describer, Say, named it Doryphora decemlineata, and that at first that designation acquired such extensive currency that it was all but universally adopted ; and many people from old habit or deference to general usage, even when they know it to be an error, still use it ; but all entomologists know that it is not a Doryphora, but a portion of the great genus Chrysomela, without going into other details. The difference between them can be very easily pointed out by one single character. Doryphora is a massive Chrysomela with a strong spike projecting forwards from the middle (the mesosternum) of the under side, while Chrysomela has no such spike. The former is a genus peculiar to the South American region, including Central America, and contains the largest, finest, and most beautiful species of the family. Some of them are somewhat similarly marked to the Colorado beetle, which no doubt led to Say mistaking the genus. But although the Colorado species and its allies are clearly enough Chrysomelæe, systematists in arranging that genus have broken it up into several 'sub-genera or new genera, and the latest authority (Chapuis) has placed them in a genus named Leptinotarsa, but at the same time indicates his opinion that a further subdivision must take place, which will leave the Colorado beetle and its relations in a sub-genus by themselves, as was long ago ( 1837$)$ proposed by M. Chevrolat, under the name of Polygramma. For the characters of these subdivisions we refer to M. Chapuis's genera, and for the specific characters of the species falling under Polygramma to Stahl's diagnosis and Mr. Riley's first

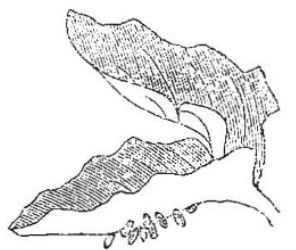

Potato leaf with eggs of Colorado Beetle on under side.

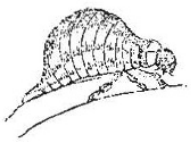

Larva of Colorado Beptle : natural size. -NOTE. The double row of not suffi:iently distinct in this cut.

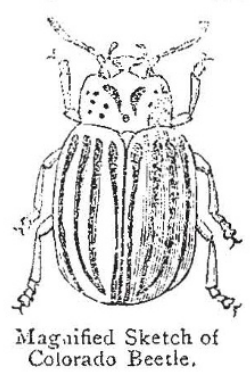
biack spots along the abilomen is

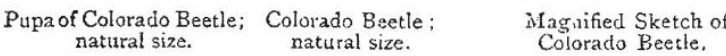

Missouri Report (1869). These are, first, the true Polygramma (Decemlineata, Say) that has occasioned all this alarm, which is the most northerly species, its native home being the eastern base of the Rocky Mountains and the prairies extending eastward. Next a variety called Multilineata by Walsh and Stahl, but which is not specifically distinct. Then a good species, Polygramma juncta, which ranges through the Confederate States of North America, and is easily recognised by two of the dorsal black lines uniting to make one thicker one. Farther to the south, about Vera Cruz and Costa Rica, \&c., there is another species very like the Colorado species, called Polygramma undecemlineata, Stahl, and which is found in enormous numbers in these parts of Mexico. Lastly Stahl records another, which we have not seen, from Mexico, under the name of novemlineata. All these feed on different plants, although probably plants all belonging to the same order, the Solanaceæ.

\section{NOTES}

The Society of Arts has awarded its Albert Medal "for distinguished merit in promoting Arts, Manufactures, or Commerce, to Jean Baptiste Dumas, member of the Institute of France, the distinguished chemist, whose researches have exercised a very material influence on the advancement of the Industrial Arts." The Society's Medals for papers read during the session, have been awarded to Prof. Barff, M.A., for his paper on "The Treatment of Iron for the Prevention of Corrosion;" J. Meyerstein, for his paper on "Stenochromy, a Novel Method of Printing in Colours ;" A. J. Ellis, F.R.S., for his paper on "The Measurement and Settlement of Musical Pitch ;" B. St. John Ackers, for his paper entitled "Deaf not Dumb ;" Commander Cameron, R.N., 